\title{
The use of non-pharmacological adjuvant therapies for cancer pain: a narrative review in the context of dance
}

O uso de terapias adjuvantes não farmacológicas para dor oncológica: uma revisão narrativa no contexto da dança

El uso de terapias adyuvantes no farmacológicas para el dolor por cáncer: una revisión narrativa en el contexto de la danza

Received: 12/15/2021 | Reviewed: 12/22/2021 |Accept: 12/30/2021| Published: 01/07/2022

Elaine Izabel da Silva Cruz

ORCID: https://orcid.org/0000-0002-9841-6914 Instituto Federal de Educação, Ciência e Tecnologia de Goiás, Brasil

E-mail: elaineiscruz@gmail.com

Aline Helena da Silva Cruz

ORCID: https://orcid.org/0000-0002-9943-5797

Centro Universitário Araguaia, Brasil

E-mail: alinehelenasc@gmail.com

Rômulo Alberto Silva Marques

ORCID: https://orcid.org/0000-0003-1712-3579 Hospital Araújo Jorge, Brasil

E-mail: romuloasmarques@hotmail.com

Rodrigo da Silva Santos

ORCID: https://orcid.org/0000-0002-9480-4362 Universidade Federal de Goiás, Brasil E-mail: rdssantos@ufg.br

Angela Adamski da Silva Reis

ORCID: https://orcid.org/0000-0002-9480-4362 Universidade Federal de Goiás, Brasil E-mail: angela@ufg.br

\begin{abstract}
Cancer is one of the leading causes of morbidity in the globe, with more than half of patients reporting pain as a result of the disease. By reducing cancer-related pain, dance has the potential to redefine the life of patients independently of their cure prognosis. This review investigated the benefits of dance as adjuvant, non-pharmacological therapy for cancer treatment. To identify studies related to this topic, we searched the Cochrane Library, PUBMED, Scielo, BVS, Embase, CINAHL, and PsycINFO databases. However, we found few published systematic reports investigating the effects of dance in cancer treatment. The numbers are even smaller when we considered the relationship between dance and cancer pain. Although there is a small number of publications on this theme, we reviewed studies that indicate that there is a positive relationship between dance practice and cancer pain management. Moreover, we found that the decline of pain contributed to the better life quality of patients with cancer. We concluded that dance is a physical practice that may improve patients' quality of life. Regarding the estimations of cancer diagnosis and pain during disease development and therapy, it is fundamental new studies and clinical trials that integrate dance as adjuvant therapy for improving cancer pain and patient's life quality.
\end{abstract}

Keywords: Dance; Therapy through dance; Cancer pain; Pain management; Cancer.

\section{Resumo}

As doenças oncológicas são uma das principais causas de morbidade no mundo, com mais da metade dos pacientes relatando dor. Ao reduzir a dor relacionada ao câncer, a dança tem o potencial de redefinir a vida dos pacientes, independentemente de seu prognóstico de cura. Esta revisão investigou os benefícios da dança como terapia adjuvante não farmacológica para o tratamento do câncer. Para identificar estudos relacionados à este tópico, pesquisamos os bancos de dados Cochrane Library, PUBMED, Scielo, BVS, Embase, CINAHL e PsycINFO. No entanto, No entanto, encontramos poucos relatórios sistemáticos publicados investigando os efeitos da dança no tratamento do câncer. Os números são ainda menores quando consideramos a relação entre dança e dor oncológica. Embora haja um número expressivamente pequeno de publicações nessa temática, revisamos estudos que indicam que existe uma relação positiva entre a prática da dança e o manejo da dor oncológica. Constatamos que o declínio da dor contribuiu para melhor qualidade de vida dos pacientes com câncer. A dança é uma prática artística e física que pode melhorar a 
qualidade de vida dos pacientes. De fato, a dança pode ser empregada como terapia adjuvante no tratamento do câncer. Diante das estimativas de diagnóstico de câncer e dor oncológica, é fundamental o desenvolvimento de novos estudos e ensaios clínicos que integrem a dança como terapia adjuvante para melhorar a dor oncológica relacionada ao câncer e a qualidade de vida do paciente.

Palavras-chave: Dança; Terapia através da dança; Dor oncológica; Manejo da dor; Câncer.

\section{Resumen}

El cáncer es una de las principales causas de morbilidad en todo el mundo y más de la mitad de los pacientes informan de dolor. Al reducir el dolor relacionado con el cáncer, la danza tiene el potencial de redefinir la vida de los pacientes, independientemente de su pronóstico de curación. Esta revisión investigó los beneficios de la danza como terapia adyuvante no farmacológica para el tratamiento del cáncer. Para identificion dear estudios relacionados con este tema, se realizaron búsquedas en las bases de datos Cochrane Library, PUBMED, Scielo, BVS, Embase, CINAHL y PsycINFO. Encontramos que hay solo unos pocos informes sistemáticos publicados que investigan los efectos de la danza en el tratamiento del cáncer. Los números son aún menores cuando consideramos la relación entre la danza y el dolor por cáncer. Aunque existe un número expresivamente pequeño de publicaciones sobre este tema, revisamos estudios que indican que existe una relación positiva entre la práctica de la danza y el manejo del dolor por cáncer. Descubrimos que la disminución del dolor contribuyó a una mejor calidad de vida de los pacientes con cáncer. La danza es una práctica artística y física que puede mejorar la calidad de vida de los pacientes. De hecho, la danza se puede utilizar como terapia adyuvante en el tratamiento del cáncer. Dadas las estimaciones de diagnóstico de cáncer y dolor por cáncer, es fundamental desarrollar nuevos estudios y ensayos clínicos que integren la danza como terapia adyuvante para mejorar el dolor relacionado con el por cáncer y la calidad de vida del paciente.

Palabras clave: Danza; Terapia a través de la danza; Dolor por cáncer; Manejo del dolor; Cáncer.

\section{Introduction}

Cancer is one of the leading causes of morbidity in the globe. Estimations from the Global Cancer Statistics (GLOBOCAN) indicated that 17 million new cancer cases were diagnosed in 2018, excluding non-melanoma skin cancer (Bray et al., 2018). These estimations show that one in eight men and one in ten women will develop cancer throughout their lives, even in countries with a low Human Development Index (HDI). In contrast, in the five African regions, the cumulative risk of death for women in 2018 was comparable to the risk observed in women from North America and high-income countries in Europe (Bray et al., 2018).

The National Cancer Institute (NCI) warns that cancer is a global health issue. In the long term, the World Health Organization estimated that 24 million new cancer cases will be diagnosed by 2035 , with an expected death rate of 14.5 million patients each year (NCI, 2016). The diagnosis of cancer has proven to be independent of the HDI levels in countries. It is known that public health measurements need to be taken, especially in developing regions. Europe has $23.4 \%$ of the total number of diagnosed cancer cases (representing 9\% of the world's population) compared with $21 \%$ of incidence in the Americas. In Asia, up to half of the cases are present in the continent; however, $60 \%$ of the world's population lives in the region. Considering Asia and Africa, there is a high mortality rate in both areas, with the percentage of death overcoming a diagnosis of cancer (Bray et al., 2018).

Cancer presents a variation of more than 100 malignant tumor types. Cancer and oncological treatments can negatively impact the physical and psychosocial aspects of individuals, often provoking fatigue, depression (Murphy, 2010), and pain. Indeed, pain is one of the most adverse reported effects of cancer being also a collateral effect of treatment (Costa et al., 2017). Moreover, pain is linked to emotional suffering due it negatively affects the patient's daily life and quality of life (NCI 2018). In addition, according to NCI (2018), pain and its intensity are linked to a higher chance of developing depression.

The Union for International Cancer Control (UICC) created the "We can. I can." campaign for triennium 2016-2018. This slogan represented the diversity of manners that can reduce the impact of cancer, in both collective and individual aspects (Brasil, 2016). In addition, to discourage the preconceptions surrounding cancer, the National Cancer Institute from the Brazilian Ministry of Health - INCA, also promoted a campaign with the slogan "cancer cannot end up our will to live" (Brasil, 2017). 
Both campaigns evidenced that the currently employed cancer treatments should not exclusively target the tumor itself. Instead, cancer patients and their fitness during therapy should be emphasized. Furthermore, it is known that multidisciplinary approaches can increase patients' quality of life during standard therapies. Additionally, some programs, even when not curative, could be adjuvant to standard care to cooperate with different phases of treatment and their effects on the patient's life.

Physical activities have been employed as part of non-pharmacological adjuvant therapies in cancer survivors (Rosa et al., 2021; Dos Santos et al., 2017; Koom et al., 2016). In the context of this therapy type, presente a potential to contribute to cancer patients by reducing pain and increasing their quality of life. Dance is relevant for cancer treatment based on the principle that it is one of the most complex activities for the brain to process.

Rhythmic movements are derived from brain instructions to the muscles. In this way, moves develop and integrate various sensorial information, such as audible, vestibular, visual, and somatosensory inputs. Thus, as a result of an intricate nervous and muscular interface, dance allows patients to integrate feelings and interpretations through movements (Dawson, 2017). Moreover, dancing increases stability, social mobility, and quality of life during aging (Dordevic et al., 2017; Rehfeld et al., 2017).

Preferences of patients and exercise enjoyment should also be taken into consideration to increase their participation in exercises (Marchica et al., 2021; Yildiz Kabak et al., 2021). On the other hand, has been described that non-pharmacological methods used to relieve pain are effective, and can contribute to changes in care protocols such as low-cost, creative, safe and that provides benefits to cancer patients, especially breast cancer (Franco et al., 2021; Yildiz Kabak et al., 2021). Few studies have been published and this review investigated the benefits of dance as adjuvant, non-pharmacological therapy for cancer treatment.

\section{Methodology}

We investigated the primary health-related databases, such as Cochrane Library, PubMed - NCBI (National Center for Biotechnology Information), SciELO (Scientific Electronic Library Online), BVS (Virtual Health Library), Embase, CINAHL (Cumulative Index to Nursing and Allied Health Literature) and PsycINFO. We used the combination of the following keywords: cancer pain, dance, dance therapy, and their corresponding Portuguese translations. When necessary, we modified our search according to each database. To avoid the lack of studies, we performed manual searches with keywords and broader analyses using keywords and similar terms.

Our primary inclusion criterion was the presence of clinical trials investigating the therapeutic effects of dance in cancer pain. In addition, the participants involved in these studies should have more than 18 years of age. We excluded studies that did not mention dance as therapy for cancer pain. In the same way, we excluded papers that used dance as therapy for cancer but did not investigate its influence on cancer pain (Figure 1). As a result, only one report was selected, which made it impossible to systematic literature review. 
Figure 1. Dance as therapy for cancer.
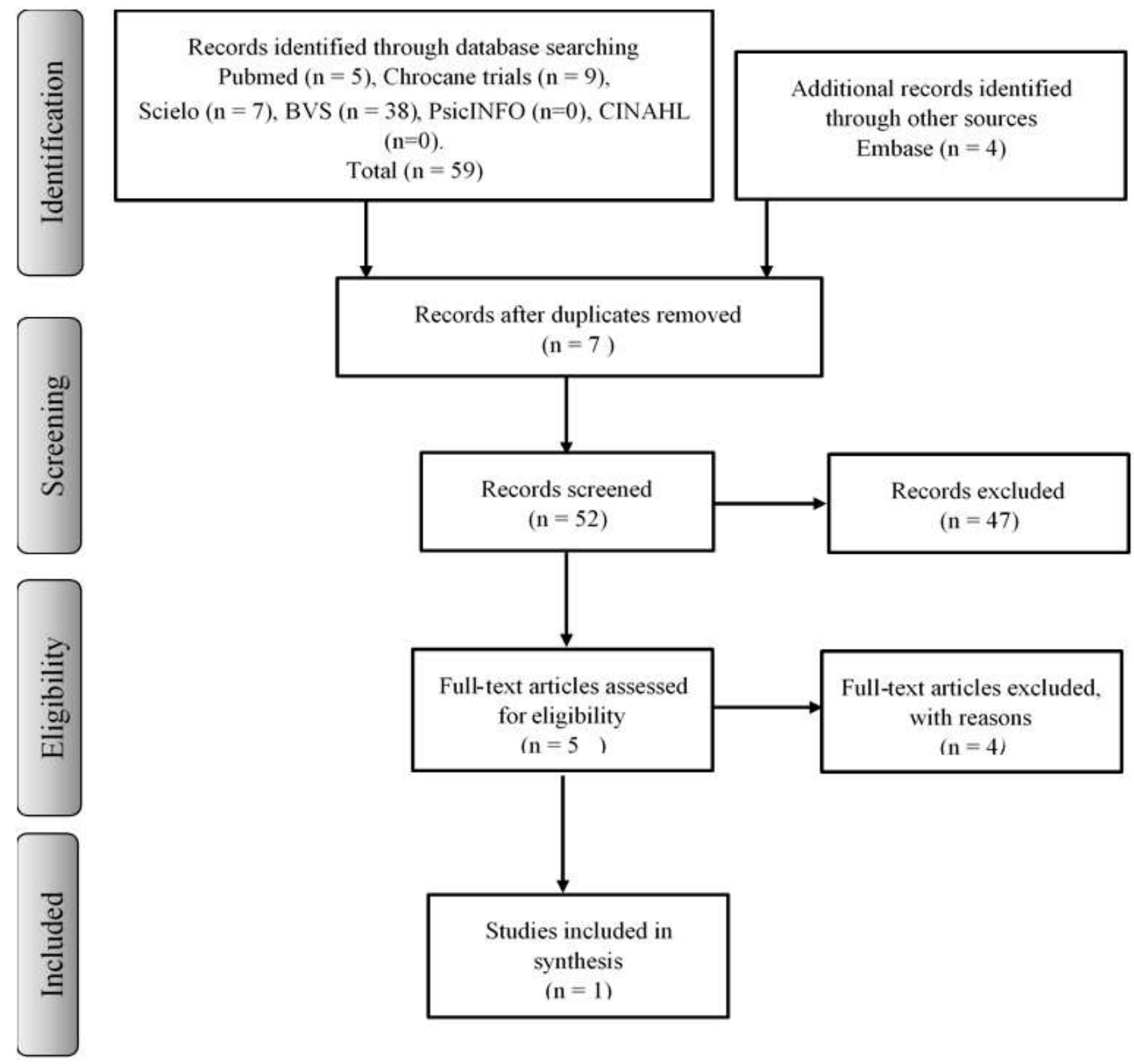

Source: Authors

\section{Results and Discussion}

This literature review aimed to describe dance as a positive correlation between practice and improvement of pain management and quality of life. Although some findings are relevant, the number of studies is even smaller for reports that aim to identify relationships between dance therapy and cancer pain.

Only one report was selected (Ho et al., 2016), this study evaluated a cohort of 139 Chinese patients with primary breast cancer that were older than 18 years of age and were waiting for or were in the first week of radiotherapy. This was a randomized study for dance movement therapy (DMT) vs. control group. The intervention included six rounds of DMT for 1h30min, twice a week, during treatment with radiotherapy. The DMT program was adapted to the Chinese culture in addition to the patient's needs. Outcome data were obtained with the aid of survey forms before and after the DMT programs. Moreover, surveys were taken during a follow-up period of three weeks after the end of the program. 
To measure the outcome of cancer pain, this important Chinese study employed the Bried Pain Inventory, which is a scale with 11 points of intensity for measuring pain and its influence on patients' routine. The results showed a significant effect of DMT in the severity and interference in pain. The DMT group reported an increase of $25 \%$ in relief and interference pain on radiotherapy compared with the control group.

This study also reported an improvement in patients stress. However, there was no significant influence of DMT on anxiety, depression, fatigue levels, sleep disturbance, and life quality. These results are in contrast with those from other studies (Kaltsatou et al., 2011; Pisu et al., 2017; Sturm et al., 2014; Szalai et al., 2017). On the other hand, it is relevant to state that these reports did not employ similar dance modalities.

Due few studies, we found authors used the dance in different modalities, styles, techniques, and with separate practices. Thus, regarding our work limitations, similar peculiarities that potentialize dance in the perspective of this review also impair the comparison between distinct studies found.

\section{Features associated to pain and its perception by patients}

Pain is the primary reason for seeking medical assistance. The International Association for the Study of Pain (IASP) defines pain as a sensorial and emotional unpleasant experience that is a consequence of potential or real tissue damage. IASP, however, states that pain is always subjective since each links such concepts with experienced lesions (IASP, 2011). Physical pain is intrinsically unpleasant and was developed as a survival mechanism by directing behaviors that avoid lesions. However, in modern societies, acute pain has a major negative impact on human well-being. Acute pain thus lacks a behavioral advantage for our species (Mouraux \& Lannetti, 2018).

The brain is the primary organ of pain. Painful stimuli are conducted as nociceptive signals to the central nervous system through the spinal cord. Then, the activation of ascending fibers reaches the superior centers. In addition, generating, transmitting, and modulating pain is directly associated with the endocrine system. Several hormones modulate pain, such as proopiomelanocortin, adrenocorticotropin and endorphins, thyroid system hormones, growth hormones, prolactin, melatonin, insulin, calcitonin, somatomedin, somatostatin, histamine, and vasopressin. The relationship between perceived pain and its endocrine effects suggests that hormones can act as critical biomarkers for chronic pain syndromes and be developed as therapeutic agents for reducing pain (Chen et al., 2016).

Pain neuroscientists aim to improve the basic knowledge of the neural mechanisms that process sensorial perception of pain to identify more efficient methods to treat and reduce patient suffering. Moreover, the research for neural biomarkers for pain stratification may predict medication response to the development of personalized treatment. A biomarker can show high utility in identifying groups of patients that may respond with more sensitivity and specificity to treatment (Mouraux \& Lannetti, 2018). Since patients expect to have adequate pain relief, treating and managing pain is a responsibility of the professional team in health care environments. Although verbal reports obtained from large cohorts and controlled experiments are trustworthy, the use of report-independent tools for measuring the presence and intensity of pain may be necessary in some cases (Ellison, 2017; Mouraux \& Lannetti, 2018).

Context, transmission, and perception of pain are decisive for the subjective experience of pain, which can also be influenced by genetic, gender, cultural, expectation, physical and mental health, past pain, and age factors (Ellison, 2017). As a result of the features linked to pain and its consequences (Figure 2), measuring and relieving cancer-related pain has been one of the most challenging practices in the clinical setting. 
Figure 2. Symptoms and consequences (physiological and social) associated with pain and pain perception.

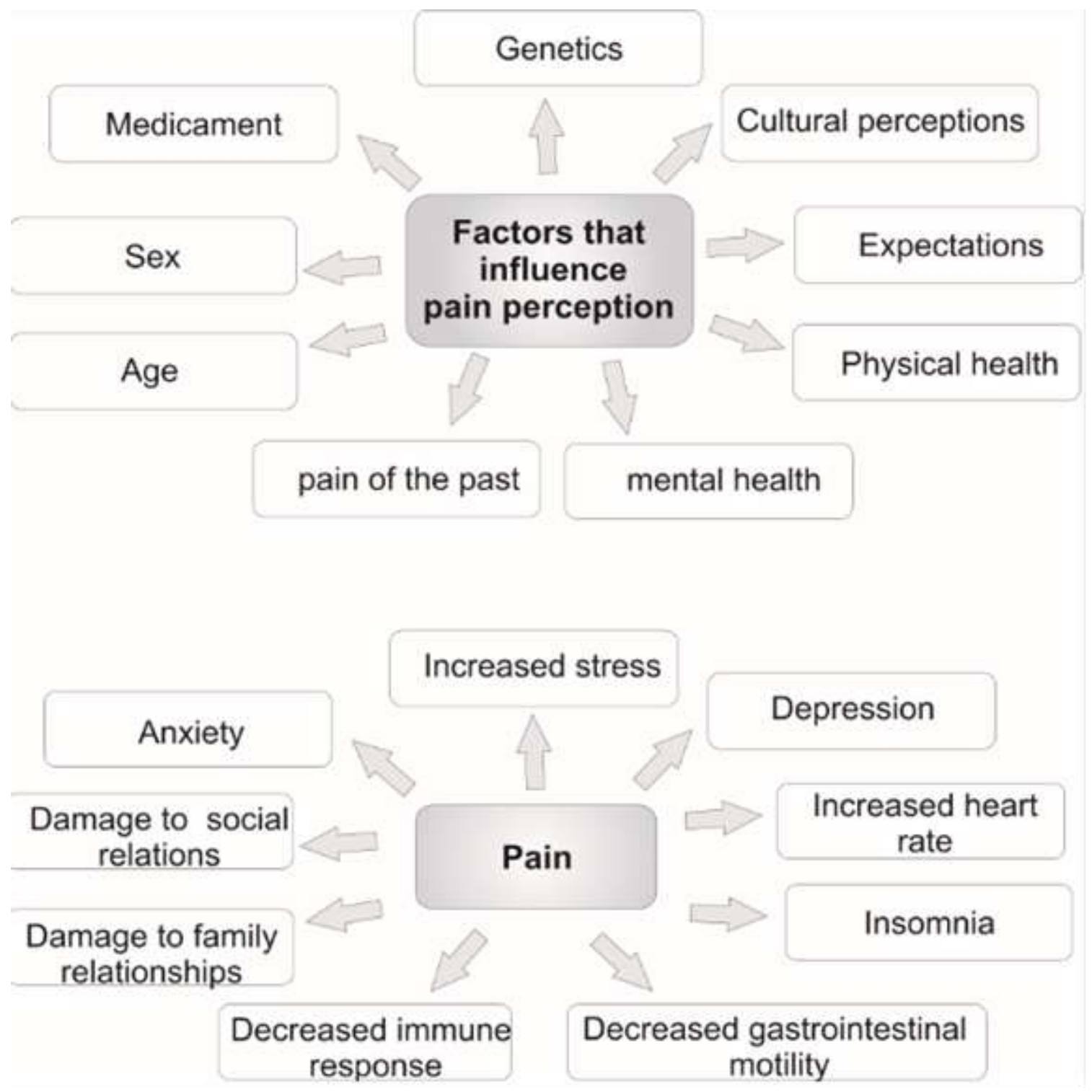

Source: Authors.

\section{Cancer pain: symptoms and implications}

The statistical reports from the Cancer Pain Research Consortium (2016) show that 60-70\% of cancer patients reported having pain and $70-80 \%$ are afraid of feeling pain. Around $90 \%$ of cancer pain cases can be managed; however, only $50 \%$ of patients with pain seek relief. In cancer, pain is more frequent in advanced stages. Painful events are often linked to inflammation-related conditions. Moreover, inflammation is one of the primary causes of cancer symptoms, namely fatigue, cachexia, and anorexia (Vendrell et al., 2015).

A systematic literature review performed with 52 studies spanning four decades investigated the prevalence of pain in patients with cancer according to different disease staging and types. More than one-third of patients reported their experienced pain as being moderate or high. The results of this study showed a high prevalence of pain in individuals. Interestingly, $64 \%$ of patients had a metastatic, advanced, or terminal disease, 59\% were under treatment with chemotherapeutic agents, and only $33 \%$ were cured (van den Beuken-van Everdingen et al., 2007). 
The impact of pain in patients was also investigated in a cohort of 109 individuals from Taiwan. This report demonstrated that there was an inverse correlation between patients' pain intensity reports and quality of life. This observation indicated that patients experiencing more pain had lower levels of functional and global aspects of life quality (Liang et al., 2015). The evaluation of 64 North American patients experiencing cancer pain revealed that treating this condition led to reduced emotional suffering. Unfortunately, lower well-being levels and physical performance status were linked to suicidal tendencies (O’Mahony et al., 2010). Similarly, Costa et al., 2017, reported a significant negative correlation between painful events and quality of life in patients with cancer. This study also suggested that how pain is perceived in its multifactorial aspects influences subjects' quality of life.

Considering the state of pain from the participants, a controlled cross-sectional study conducted with 124 patients with cancer from China - 64 reported pain revealing that unmanaged pain was a significant risk predictor to anxiety and depression (Li et al., 2017). The authors also discussed a lack of controlled studies used for comparison with their results. However, a non-controlled study that applied similar pain and psychological measurements as of Li et al., 2017, identified similar levels of anxiety and depression in American patients experiencing.

Pain may also be a consequence of anemia, and this is commonly diagnosed together with the development of inflammatory processes. Anemia can develop as a result of cancer as well as continuous bleeding, nutritional deficiency, bone marrow lesion, or immunological impairment of the erythropoietic response (Demetri, 2001). The development of anemia after chemotherapy provokes several collateral effects that compromise the patient's quality of life and treatment efficacy. The most common symptoms of anemia are headache, thorax ache, fatigue, cold skin, dizziness, palpitations, lung edema, cardiac insufficiency, depression, and cognitive damage (Demetri, 2001; Gálffy, 2013; Ludwig \& Strasser, 2001).

The severity of anemia and the development of alarming symptoms are associated with different factors such as physiological state of the patient, anemia severity, time for anemia development, and age. On the other hand, an increase in hemoglobin levels indicates that there was an improvement in symptoms and, consequently, in the patient's life quality (Ludwig \& Strasser, 2001). Anemia and fatigue are significantly associated with cancer. Although fatigue may be multifactorial, anemia can contribute to the exhaustion of treated individuals. In this manner, treating anemia may help to minimize its symptoms and increase the response to treatment (Demetri, 2001).

For the understanding of how combining conventional and non-pharmacological therapies for anemia treatment, a study described detailly in a review on sickle cell anemia. Pain is the most common symptom of individuals with this genetic condition. Evidence supports that the use of non-drug therapies in treating psychological and social complications of pain in cancer patients. The most common treatments include physical activities, massage therapies, aquatic rehabilitation, and social therapies associated with standard care treatments (Willians \& Tanabe, 2016).

Based in this same principle of treating sickle cell anemia patients with non-pharmacological approaches may be employed for treating and cancer pain. The above-mentioned data point towards the necessity of highlighting patients' condition and not only cancer itself. With this approach, the symptoms that negatively impact the daily activities of patients can be minimized. Papathanassoglou (2014) investigated the advance in pain research and found that negative emotions are risk factors for the maintenance of pain. In this manner, by suggesting practical approaches to pain management, the author described the importance of investigating the analgesic effects of distraction and physical activities.

\section{Dance}

Dance is a universal human behavior and is as ancient as the movements of running and walking (Brown et al., 2006). Since the beginning of human civilization, our species has used dance for several reasons: in peace and war, weddings, and 
funerals, and in sowing and harvesting. Through dance, it is still possible to communicate without the use of words (Mendes, 1985), and, since then, each social change has been accompanied by a dance that represents the living moment.

It stands a chance that dance acted as a primitive form of language. Brown and Parsons (2008) showed that the movement of legs activates the right hemisphere of the brain, which corresponds to Broca's area. This region is known to control speech. Therefore, the findings by the authors are in keeping with the concept that language was developed from an initial system of signals before becoming vocal sounds. Humans develop dance according to their experience while new meanings are given to their life. This occurs due the human body creates, executes, and experiences dancing. Moreover, a body that thinks, acts, and feels can transform itself and others (Marques, 2010). Furthermore, dance allows the investigation of how our brain integrates movement, sound, motor experience, artistic creativity, and performance while involving the active practice of sensorial-motor abilities (Karpati et al., 2015).

Dancing behavior is inherent to humans, thus the interest of neuroscience on understanding why people unconsciously move their feet to the rhythm of the music. A study showed that individuals that accompanied the pace of a song had their inferior region of the auditive pathway (more specifically in a subcortical structure referred to as medial geniculate nucleus) more active. However, when individuals listened to music and did not move their legs, there was no activation of the blood influx to the earlier mentioned brain region. This observation suggests that the medial geniculate nucleus is involved in synchronization and not in the listening act.

In addition, dance uniqueness consists in the fact that when individuals communicate through art, into their culture, they are also amused and physically active. Karpati et al., 2015, demonstrate that dance involves athletic and artistic training. Thus, dancing is different for each athlete and, possibly for other groups or artists. Dancing is a daily activity: in homes, streets, clubs, churches, and gyms. In the digital world from YouTube to soccer commemorations and cultural festivals, dance is an intrinsic activity for humans. As art, dance is considered as a language, such as a creative display seen as positive and entertainment. Art, as a product of human creativity, can be learned through study, practice, and observation. Through art, it is possible to describe objects, events, moments and express feelings, opinions, and behaviors. Creativity, as a consequence of the artist's brain, can facilitate the interaction between different people that admire a specific piece of art, music, poem, or dance (Vida et al., 2016).

In this perspective, dance is part of human culture by integrating art and physical exercise. Such versatility and benefits seen from the intersection areas (Figure 3) indicated that dance might enhance human health. Aerobic exercise could be reduced fatigue and increase the life quality of patients with cancer (Dos Santos et al., 2017). Similarly, art therapy including art appreciation can also contribute to well-being (Koom et al., 2016). 
Figure 3: Physiological and social benefits associated with the practice of dance.
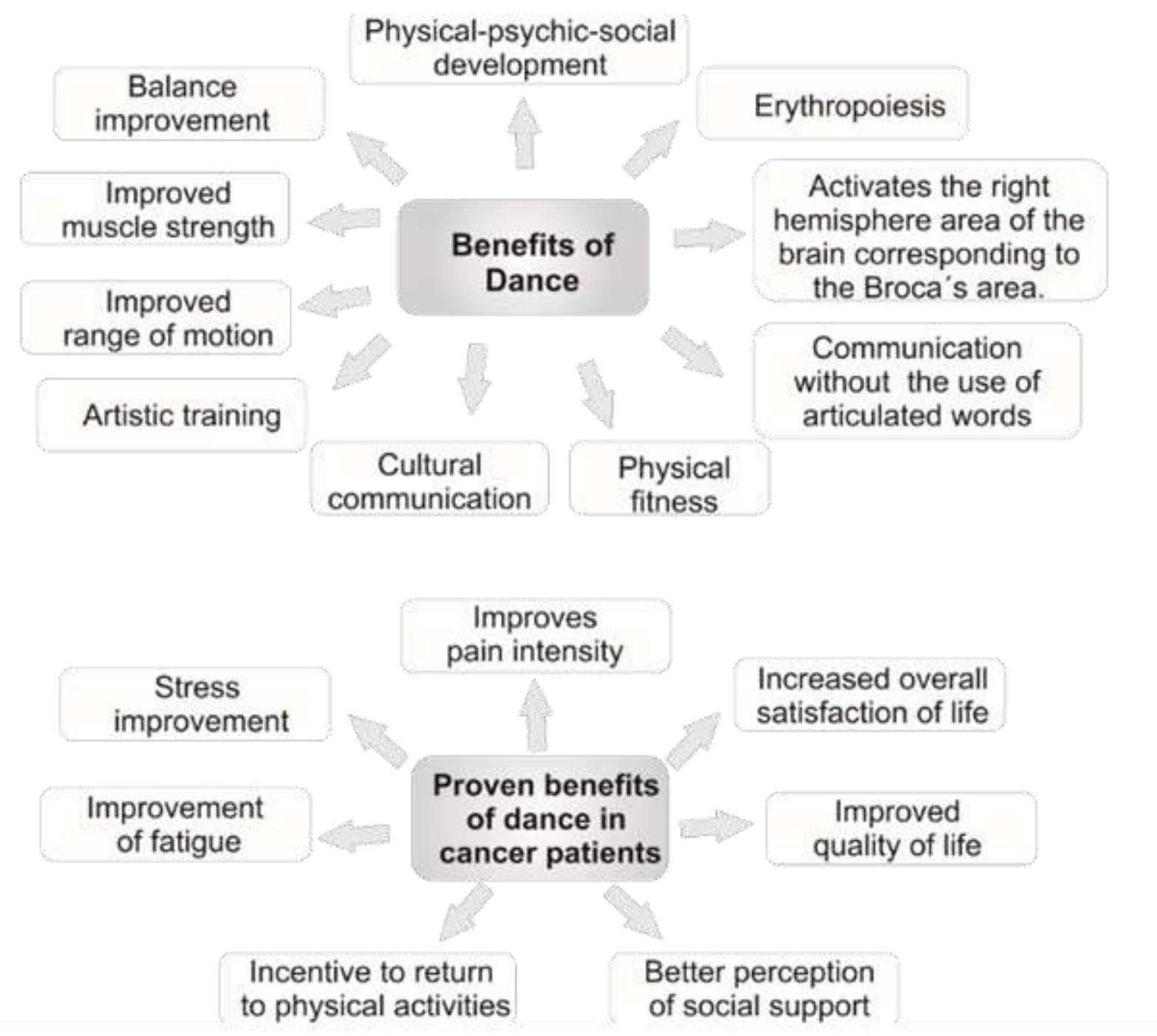

Source: Authors.

\section{Proven benefits of dance for patients with cancer}

As previously discussed, dance promotes psychosocial development, equilibrium, muscular strength, movement amplitude, physical conditioning, artistic training, erythropoiesis, activates the Broca's region, influences cultures, and allows communication without the use of words. On the other hand, few studies have been demonstrated the contribution of dance in cancer patients.

Dance offers an exceptional opportunity for studying the human brain's plasticity and human-behavior interface (Karpati et al., 2015). Additionally, a randomized clinical trial performed in Greece demonstrated that patients with breast cancer that practiced traditional dance for 24 weeks had better physical functions, fewer depression symptoms, and higher satisfaction with life (Kaltsatou et al., 2011). An American pilot randomized clinical trial showed that 12-week interventions with saloon dance improved cancer patients' active behavior and quality of life with their partners (Pisu et al., 2017).

Aside from the social benefits, a quasi-randomized trial performed in Germany with patients for five weeks concluded that dance was an efficient approach for treating cancer-related fatigue (Sturm et al., 2014). Furthermore, the benefits of belly 
dancing for women patients with cancer have been extensively reported (INCA 2017, Szalai et al., 2017). A non-randomized clinical trial conducted in Hungary demonstrated that 12 months of intervention with belly dancing was able to improve patients' quality of life, perception of social support, and life satisfaction compared with patients without this complementary treatment (Szalai et al., 2017).

Table 1 presents the results from clinical trials involving dance in cancer treatments. These studies evidence that dance as art and physical activity contributes to less depression, anxiety, and improves social abilities in patients with cancer. In addition, dancing helps the global development of movements and their functional independence, which can reduce cancer pain.

Table 1. Benefits of dance to cancer patients.

\begin{tabular}{|c|c|c|c|c|c|}
\hline Type of Study & $\begin{array}{l}\text { Intervention } \\
\text { Period }\end{array}$ & Result & Year & Country & Authors \\
\hline Randomized Clinical Trial & 24 weeks & $\begin{array}{l}\text { Dancing has had a positive impact on } \\
\text { breast cancer survivors, with benefits on } \\
\text { physical function, depressive symptoms, } \\
\text { and life satisfaction. }\end{array}$ & 2011 & Greece & Kaltsatou et al \\
\hline $\begin{array}{l}\text { Randomized Clinical Trial - } \\
\text { Pilot }\end{array}$ & 12 weeks & $\begin{array}{l}\text { Dancing has been an important tool for } \\
\text { cancer survivors to return to a physically } \\
\text { active life and improve their quality of } \\
\text { life with their partners/spouses. }\end{array}$ & 2017 & USA & Pisu et al \\
\hline $\begin{array}{c}\text { Quasi-randomized Clinical } \\
\text { Trial }\end{array}$ & 5 weeks & $\begin{array}{l}\text { Dancing can be an effective approach to } \\
\text { treating cancer-related fatigue. }\end{array}$ & 2014 & Germany & Sturm et al \\
\hline $\begin{array}{l}\text { Non-randomized Clinical } \\
\text { Trial }\end{array}$ & 12 weeks & $\begin{array}{l}\text { Cancer patients who participate in a } \\
\text { belly dance program have a better } \\
\text { quality of life, perceived social support, } \\
\text { and increased overall life satisfaction } \\
\text { than patients who do not receive any } \\
\text { complementary treatment. }\end{array}$ & 2017 & Hungary & Szalai et al \\
\hline
\end{tabular}

Source: Authors.

Specifically, these reports demonstrated that combining dance and cancer treatment encourages patients to return to physical activities, which leads to less stress and promotes more quality of life. Moreover, there are different approaches to how dance can aid the adverse effects of pain during cancer treatment.

\section{Conclusion}

A critical, reflexive investigation on cancer treatment is fundamental to increase strategies for non-pharmacological adjuvant therapy. Dance offers an exceptional opportunity as strategies for improving pain management and quality of life in cancer patients.

\section{Acknowledgments}

Universidade Federal de Goiás, Faculdade de Medicina, Programa de Pós-Graduação em Ciências da Saúde, Goiânia, GO, Brazil.

Instituto Federal de Educação, Ciência e Tecnologia de Goiás, Anápolis, GO, Brazil. 
Research, Society and Development, v. 11, n. 1, e30411124771, 2022

(CC BY 4.0) | ISSN 2525-3409 | DOI: http://dx.doi.org/10.33448/rsd-v11i1.24771

\section{References}

Brasil. (2016). Sala de Imprensa - Release: Campanha de prevenção do câncer enfatiza hábitos de vida saudáveis. In: Instituto Nacional do Câncer (INCA).https://www.inca.gov.br/sites/ufu.sti.inca.local/files/media/document/dieta_nutricao_atividade_fisica_e_cancer_resumo_do_terceiro_relatorio_de_esp ecialistas_com_uma_perspectiva_brasileira.pdf

Brasil. (2017). Datas institucionais: 27 de novembro - Dia Nacional de Combate ao Câncer 2017. In: Instituto Nacional do Câncer (INCA). Full text available at: https://www.inca.gov.br/campanhas/dia-nacional-de-combate-ao-cancer/2017/vontade-de-viver

Bray. F., Ferlay, J., Soerjomataram, I., Siegel, R.L., Torre, L.A. \& Jemal, A. (2018). Global Cancer Statistics 2018: GLOBOCAN Estimates of Incidence and Mortality Worldwide for 36 Cancers in 185 Countries. CA: A Cancer Journal for Clinicians, 68(6):394-424. https://doi.org/10.3322/caac.21492

Brown, S. \& Parsons, L.M. (2008). The Neuroscience of Dance. Scientific American, 299(1),78-83. https://doi.org/ 10.1038/scientificamerican0708-78

Brown, S., Martinez, M.J. \& Parsons, L.M. (2006) The Neural Basis of Human Dance. Cerebral Cortex, 16(8),1157-67. https://doi.org/10.1093/cercor/bhj057

Chen, X., Zhang, J. \& Wang, X. (2016). Hormones in pain modulation and their clinical implications for pain control: a critical review. Hormones (Athens), 15(3):313-320. https://doi.org/10.14310/horm.2002.1696.

Costa, W.A., Monteiro, M.N., Queiroz, J.F. \& Gonçalves, A.K. (2017). Pain and quality of life in breast cancer patients. Clinics (São Paulo): 72(12):758-763. doi: $10.6061 /$ clinics/2017(12)07

Dawson, B. (2017). Dancers Talk About Neurology More Than Neurologists Talk About Dancing. The Neurologists Are Imbalanced. Clinical nurse specialist CNS. 31(3):174-175. https://doi.org/10.1097/NUR.0000000000000289

Demetri, G.D. (2001). Anaemia and its functional consequences in cancer patients: current challenges in management and prospects for improving therapy. British journal of cancer 84(Suppl 1): 31-37. https://doi.org/10.1054/bjoc.2001.1750

Dordevic, M., Hökelmann, A., Müller. P., Rehfeld, K. \& Müller, N.G. (2017). Improvements in orientation and balancing abilities in response to one month of intensive slackline training. a randomized controlled feasibility study. Frontiers in Human Neuroscience. 11:55:1-12. https://doi.org/10.3389/fnhum.2017.00055

Dos Santos, W.D.N., Gentil, P., de Moraes, R.F., Júnior, J.B.F., Campos, M.H., Lira, C.A.B. \& Júnior, R.F., et al. (2017) Chronic Effects of Resistance Training in Breast Cancer Survivors. BioMed Research International, vol. 2017, Article ID 8367803, 18 pages. https://doi.org/10.1155/2017/8367803

Ellison, D.L. (2017). Physiology of Pain. Critical care nursing clinics of North America 29(4):397-406. https://doi.org/10.1016/j.cnc.2017.08.001

Gálffy, G. (2013). The treatment of chemotherapy-induced anemia in lung cancer patients. Magy Onkol. Mar;57(1):39-49. doi: MagyOnkol.2013.57.1.39. Epub 2013 Feb 10. Review. Hungarian.

Ho, R.T., Fong, T.C., Cheung, I.K., Yip, P.S. \& Luk, M.Y. (2016). Effects of a Short-Term Dance Movement Therapy Program on Symptoms and Stress in Patients with Breast Cancer Undergoing Radiotherapy: A Randomized, Controlled, Single-Blind Trial. Journal of pain and symptom management May;51(5):824-831.

Internacional Association for the Study of Pain - IASP. (2011). Part III: Pain Terms: A Current List with Definitions and Notes on Usage. In: Descriptions of Chronic Pain Syndromes and Definitions of Pain Terms. http://www.iasp-pain.org/PublicationsNews/Content.aspx?ItemNumber=1957\&navItemNumber=677

INCA. (2017). Reabilitação: Como a dança pode se tornar aliada na recuperação de quem enfrenta um câncer. Revista Rede Câncer. Full text available at: http://www2.inca.gov.br/wps/wcm/connect/e87ba9004f913a7a97e9d776651c600b/09_RC36_reabilitacao.pdf?MOD=AJPERES

Yildiz Kabak V., Gursen C., Aytar A., Akbayrak T. \& Duger T. (2021). Physical activity level, exercise behavior, barriers, and preferences of patients with breast cancer-related lymphedema. Support Care Cancer. 29(7):3593-3602. https://doi.org/doi: 10.1007/s00520-020-05858-3

Kaltsatou, A., Mameletzi, D. \& Douka, S. (2011). Physical and psychological benefits of a 24-week traditional dance program in breast cancer survivors. Journal of bodywork and movement therapies 15(2):162-167. https://doi.org/10.1016/j.jbmt.2010.03.002

Karpati, F.J., Giacosa, C., Foster, N.E., Penhune, V.B. \& Hyde, K.L. (2015). Dance and the brain: a review. Annals of the New York Academy of Sciences, 1337:140-146. https://doi.org/10.1111/nyas.12632

Koom, W.S., Choi, M.Y., Lee, J., Park, E.J., Kim, J.H., Kim, S.H. \& Kim, Y.B. (2016) Art therapy using famous painting appreciation maintains fatigue levels during radiotherapy in cancer patients. Radiation oncology journal, 34(2): 135-44.

Li, X.M., Xiao, W.H., Yang, P. \& Zhao, H.X. (2017). Psychological distress and cancer pain: Results from a controlled cross-sectional survey in China. Scientific Reports 7: 1-9, article:39397.

Liang, S.Y., Wu, S.F., Chao, T.C., Tseng, L.M., Wu, W.W., Wang, T.J. \& Lu, Y.Y. (2015). The impact of pain on the quality of life of Taiwanese oncology patients. Pain Management Nursing: Apr;16(2):128-36.

Ludwig, H. \& Strasser, K. (2001). Symptomatology of anemia. Seminars in oncology 28(2 Suppl 8):7-14. https://doi.org/10.1016/S0093-7754(01)90206-4

Franco C.L., Santos, E. S., Ribeiro, C.J.N, Santos, K.O.C.A., Santos, M.S., Oliveira, M.I.N., Nunes, M.S., Alves, J.A.B., \&Ribeiro, M.C.O. (2021). Métodos não farmacológicos no alívio da dor relacionada ao rastreamento e diagnóstico do câncer de mama: revisão de escopo. Research, Society and Development. 10(10):e446101019173. https://doi.org/10.33448/rsd-v10i10.19173 
Research, Society and Development, v. 11, n. 1, e30411124771, 2022

(CC BY 4.0) | ISSN 2525-3409 | DOI: http://dx.doi.org/10.33448/rsd-v11i1.24771

Marchica P., D'Arpa S., Magno S., Rossi C, Forcina L., Capizzi V., Oieni S., Amato C., Piazza D.\& Gebbia V. (2021). Integrated Treatment of Breast Cancerrelated Lymphedema: A Descriptive Review of the State of the Art. Anticancer Res. 41(7):3233-3246. https://doi.org/doi: 10.21873/anticanres.15109

Mairbäurl, H. (2013). Red blood cells in sports: effects of exercise and training on oxygen supply by red blood cells. Frontiers in physiology 4:332:1-13. https://doi.org/10.3389/fphys.2013.00332

Marques, I. (2010). Linguagem da Dança: arte e ensino.1.ed. Digitexto, São Paulo.

Maurer, A.J., Lissounov, A., Knezevic, I., Candido, K.D. \& Knezevic, N.N. (2016). Pain and sex hormones: a review of current understanding. Pain management 6(3):285-96. https://doi.org/10.2217/pmt-2015-0002

Mendes, M.G. (1985) A Dança. $1^{\text {a }}$ ed (Séries Princípios). Ática, São Paulo.

Mouraux, A. \& Iannetti, G.D. (2018). The search for pain biomarkers in the human brain. Brain - A Journal of Neurolgy 141 (12): $3290-3307$. https://doi.org/10.1093/brain/awy281

Murphy, R.M. (2010). Waiting for a Cure: Balancing Medicine and Quality of Life for people Living with Cancer. Proceedings of the Nova Scotian Institute of Science (NSIS), v.45, n.2, p. 112-124.

NCI. (2016). Why Global Cancer Research Is Critical to Progress against the Disease. In: National Cancer Institute. Full text available at: https://www.cancer.gov/research/areas/global-health

NCI. (2018). Impact on Function and Quality of Life. In: National Cancer Institute. Full text available at: https://www.cancer.gov/about-cancer/treatment/sideeffects/pain/pain-hp-pdq\#link/_237_toc

O’Mahony, S., Goulet, J.L. \& Payne, R. (2010). Psychosocial distress in patients treated for cancer pain: a prospective observational study. Journal of Opioid Management 6(3), 211-222.

Papathanassoglou, D.E. (2014). Recent advances in understanding pain: what lies ahead for critical care? Nursin in Critical Care 19, no 3: 110-113.

Pisu, M., Demark-Wahnefried, W., Kenzik, K.M., Oster, R.A., Lin, C.P., Manne, S., Alvarez, R. \& Martin, M.Y. (2017). A dance intervention for cancer survivors and their partners (RHYTHM). Journal of cancer survivorship: research and practice. Jun;11(3):350-359.

Rehfeld, K., Müller, P., Aye, N., Schmicker, M., Dordevic, M., Kaufmann, J., Hökelmann, A. \& Müller, N.G. (2017). Dancing or Fitness Sport? The Effects of Two Training Programs on Hippocampal Plasticity and Balance Abilities in Healthy Seniors. Frontiers in human neuroscience. eCollection.11: 305. https://doi.org/10.3389/fnhum.2017.00305

Rosa V.D.L, da Silva Reis A.A., Alves R.R, Dos Anjos C.S, Freitas-Junior R. (2021). The importance of discussing physical exercise in women with breast cancer-related lymphedema. Support Care Cancer. https://doi.org/doi: 10.1007/s00520-021-06541-x

Sturm, I., Baak, J., Storek, B., Traore, A. \&Thuss-Patience, P. (2014) Effect of dance on cancer-related fatigue and quality of life. Support Care Cancer; Aug. 22(8): 2241-2249.

Szalai, M., Lévay, B., Szirmai, A., Papp, I., Prémusz, V. \& Bódis, J. (2015). A clinical study to assess the efficacy of belly dancing as a tool for rehabilitation in female patients with malignancies. European journal of oncology nursing: the official journal of European Oncology Nursing Society. Feb; 19(1):60-65.

The Cancer Pain Research Consortium. (2016). Managing cancer pain. A Treatment Guide for Patients and their Families Patient Resource. Resource Publishing. https://www.cancerpainresearchconsortium.org/assets/cancer\%20pain\%20guide\%202016.pdf

Van den Beuken-van Everdingen, M.H., de Rijke, J.M., Kessels, A.G., Schouten, H.C., van Kleef, M. \& Patijn, J. (2007). Prevalence of pain in patients with cancer: a systematic review of the past 40 years. Annals of Oncology 18: 1437-1449.

Vendrell, I., Macedo, D., Alho, I., Dionísio, M.R. \& Costa, L. (2015). Treatment of Cancer Pain by Targeting Cytokines. Mediators of inflammation 2015: 984570. 11 pages. http://dx.doi.org/10.1155/2015/984570

Vida, D., Marina, R.B., Marijana, B.P. \& Marija, B.P. (2016). Arts, Brain and Cognition. Psychiatria Danubina, 28(4): 343-348.

Williams, H. \& Tanabe, P. (2016). Sickle Cell Disease: A Review of Nonpharmacological Approaches for Pain. Journal of pain and symptom management 51(2):163-77. https://doi.org/10.1016/j.jpainsymman.2015.10.017 